\title{
The MENA Saga
}

\section{Anis H. Bajrektarevic*}

The MENA theatre is situated in one of the most fascinating locations of the world, the Middle East and North Africa. It represents, along with the BalkansCaucasus, the only existing land corridor that connects three continents. It also holds over a half of the world's proven oil-gas reserves (56 percent - oil, 48 percent - gas). Furthermore, the Gulf OPEC states and Libya have by far the lowest costs of oil extraction, thanks to the high crude purity (measured by overall properties such as the state of aggregation, excavation gravity, viscosity, weight, sulfuric content and other contaminants) which simplifies and reduces the cost of the refinement process. These petrol-exporters also enjoy the close proximity to open warm seas for low-cost, fast and convenient overseas shipments. Hence, the costs per barrel of crude for Libya and the Persian Gulf states are under US\$ 5; for other OPEC members, below US\$10. This is in a sharp contrast to countries such as the US, Russia, Norway, Canada and many others that bear production costs of several tens of US\$ per barrel, according to the International Energy Agency (IEA).

Therefore, it is an absolute imperative for the external/peripheral powers to dominate such a pivotal geo-economic and geopolitical theatre by simply keeping its centre "soft," and pre-empting, preventing or hindering any emancipation that might come through any indigenous socio-political modernisation. This is the very same imperative that has remained a dominant rationale of inner European and Asian machtpolitik for centuries.

No wonder the competition taking place in the MENA theatre, with its long history of external domination or interference (and largely pertaining to the Versailles, Anglo-French drawn borders), is harsh, multi-dimensional and unpredictable. The region is predominantly populated by Sunni (Arab) Muslims. With its high population density and a demographic growth far outpacing any economic counterpart, and a very young median population (on average 23-27 years old), frequently lacking any universal access to education, health and housing, the scene seems to be dominated by juveniles, often angry males, mainly unemployed or underemployed, but socially mobilised. ${ }^{1}$ Fuelled by severe socioeconomic exclusion, and exacerbated by exploitation of the Shia-Sunni and Muslim-Jewish antagonisms, political radicalisation is surely one of the most effective instruments of tacit control and the preservation of local governing authorities. These remain far from incapacitated, however predatory, alienated, unauthentic and weak they may be. 
Each and every one of the predominantly Sunni-Muslim Balkans-MENA countries of the secular republican type, where the external powers have brokered the political settlement, often by compromising the very sovereignty and territorial integrity, ${ }^{2}$ is enveloped in what seems to be a series of perpetuated instabilities, remaining thus paralysed. So far, not a single absolutistic monarchy has been significantly affected. From Bosnia, nearly 20 years ago, then Kosovo, Afghanistan, Iraq and Libya as well as in the post-'Spring' Egypt, Tunisia, Yemen, all the way to "ungoverned" Mali, South Sudan and Algeria's south, and up to the post-assassination, revolt-torn Tunis or anti-Avanti Mursi Cairo, a purposely dysfunctional and indecisive central government seems to have been put in place. ${ }^{3}$

Conclusively, most observers would agree that while the so-called Arab Spring had a cross-Arab ripple effect, this was far from being a pan-Arab movement. It was more of a spontaneous social revolt, a series of events connected more by AlJazeera's potted coverage of them than any directional process. To channel the energy of something so unexpectedly inflammatory and trans-nationally Arab, while studiously avoiding the spirit of pan-Arabism, let alone any hint of real structural socio-economic reform and political emancipation, was something that could have only been achieved by lighting the torch of Islamism. Playing on a single string couldn't possibly bring about the blossoms of a true Spring! How could MENA democratisation possibly be realised when primary loyalties are forcibly returned to sect, tribe or ethnicity? This dilemma relates not only to democracy, but also to the very quest of secularism - for the one presupposes the other - as history has shown ever since the French Revolution. In this or any other part of the (developing) world, democracy without secularisation of state leads to a dysfunctional, destabilising and self- defeating government. ${ }^{4}$ The current state of the MENA republics affected by the Arab Spring, as well as that of the Gulf Cooperation Council (GCC) monarchies, provides the best proof of this.

For one thing, as it now seems, the euphorically touted "Facebook revolutions" across MENA were simply strategic distractions innocently dressed up in the diverting banality of social media networks: the very same role those networks well played elsewhere too. ${ }^{5}$ Thus, sadly, it should be of no surprise that the broad and universal right of self-determination has been reduced to the right of internet-freedom, with many fundamental human rights currently compressed like a zip-file, emailed and entrusted to just a pair of omnipotent, self-centred and self-interested non-state and semi-state actors of unilateral globalism/egoism: private IT corporations and intelligence agencies. ${ }^{6}$

Presently, the announced reduction of the American physical presence (or "footprint") in Afghanistan, the limitations it faces in the nearly failed nuclear state of Pakistan, and the massive overextension it has suffered on the southwestern flank of the Euro-Asian continent as well as the recent US Army 
pullout from Iraq, are felt with mounting alarm within the GCC (and in France, UK, Israel and Turkey too). This change could lead to dangerous exposure to a neighbouring and increasingly assertive Iran as well as to Russia and China following. ${ }^{7}$ Right now, Syria pays a (proxy war) price for this: a multi-religious country of rich ancient cultural layers may end up entirely combusted, thereby creating a dangerous security vacuum in the heart of MENA. Or to use the words of frustration of the senior French diplomat who recently confided to the writer in Brussels: "We have to quickly delegitimize the legitimate Syrian government and topple al-Assad in order to convince Israel not to bomb Iran."

"Western national interests no longer determine the moral and political impulses of today's global community. ... Whatsoever the outcome, Syria's agony has underscored a further irreversible weakening of the West's dominant global role," claims former Indian Foreign Minister Jaswant Singh. Perhaps so: the West indeed has become too weak to build a new architecture, but it certainly remains strong enough to destabilise what it sees as its political peripheries.

Recently, the "Group of Friends of Syria" with their recognition of the socalled Syrian opposition all but brought Turkey to war with Syria. If I may at this point venture to be both instructive and predictive: the fall of al-Assad will most certainly trigger dissolution of Syria. It will also lead to a formalised federalisation of Iraq in a desperate move to prevent its total decomposition, as well as to a serious crisis of Lebanese and Jordanian statehoods, crises that will probably be beyond repair. ${ }^{9}$ The winners in such a scenario would then seem to be Israel (a country that remains enveloped in its traumatic Holocaust past and detached from its present neighbours) along with the GCC monarchies, at least in the short run. However, over the long term the "winners" would be the Kurds and Shias, even though the northern portions of Syria have already been occupied by the Turkish army for quite some time.

Consequently, with any proclamation of a Kurdish (Black Sea - Eastern Mediterranean) state, the Erdoğan government (as well as Iraq) would not be able to survive, as it has already created enough enemies at home and in its neighbours abroad. ${ }^{10}$ Ergo, besides the dispersed, rarified and terrified MENA Christians, the (modernised) Sunnis are definitely the long-term losers.

\section{Possible, yet not probable, epilogue}

However, while the cacophony of European contradictions works towards a self-elimination of the EU from the region, Turkey tries to reinsert itself. The so-called neo-Ottomanism of the current (Anatolian, eastern rural power-base) government is steering the country right into the centre of grand bargaining for both Russia and for the US. To this emerging triangular constellation, PM Erdoğan wishes to beat his own drum. 
Beyond the Arab Spring, neither will Russia effectively sustain its presence in the Middle East based on a strict pan-Arabic secular, republican and antiIslamic idea, nor will the US manage to politically and morally justify its continuous backing off of the absolutistic monarchies that are so energised by a most backward, dismissive and oppressive Wahhabism. Ankara tries its best to sublimate both tendencies in an effective manner, employing a mix of secular republican modernity leavened with a traditional, tolerant and emancipating Islam, so as to advertise this as an attractive future model across the Middle East. Simply enough, Bosporus wakes up to itself as the empiric proof that Islam and modernity work together. In fact, it is the last European nation that still has both demographic and economic growth.

Moreover, Ataturk's Republic is by the world's most successful Muslim state; never resting its development on oil or other primary-commodity exports, it has been blessed with a vibrant socio-economic sector and solid democratic institutions. This is heavy competition not only for Russia, but primarily for the insecure regime of the House of Saud (and the other GCC autocracies), which rules by direct royal decree over a country of recent effervescence, an oil-export dependent present and an improbable future. No wonder that on the ideological battlefield these two belligerent parties will be dominating the Middle East, in a phase of self-questioning that will endure beyond yet another round of calamities. The outcome will be felt significantly beyond the Arab region and will reverberate all across the Sunni Muslim world.

Ankara is attempting to promote the view that the Saudi-promoted Islam is actually a toxic, separatist and sectarian Wahhabist ideology that self-censors Muslims, and keeps them on the wrong side of history by hindering their socio-economic and political development. It does so by keeping Muslims on a permanent collision course with the rest of the world. An Islam that is Turkeypromoted would not be an armed ideology, but a modus vivendi, one which would permit progress and be acceptable to all (including non-Muslims), with a centuries-long history of success.

\section{References}

Bajrektarevic, A. (2012), Geopolitics of Technology and the Hydrocarbon Status Quo (Why Kyoto Will Fail Again), Geopolitics of Energy, 34 (1), CERI Canada 2012.

Bajrektarevic, A. (2012), Is There Life After Facebook, Addleton Academic Publishers RCP 11(2) 2012. Dassù, M. (2013), "How Obama II is likely to see Europe", Europe's World - the EU Policy Journal, IEA (2012), World Energy Outlook 2012 - Golden Rules for a Golden Age of Gas, OECD - IEA Publications.

Krugman, P. (2013), Marches of Folly, IHT/The New York Times (19 March 2013, 7).

OECD (2012), OECD Economic Outlook, (Issue 1, June 2012; and Issue 2, December 2012), OECD Publications.

Pariser, E. (2011), The Filter Bubble: What the Internet Is Hiding from You, Penguin (43). Spring 2013/23, 96. Singh, J. (2012), What Syria means to global community, Jakarta Post - Indonesia (4 September 12, 6). 
UNDP (2013), Human Development report HDR-2013 - The Rise of the South: Human progress in a Diverse World, UN - UNDP Publications.

Wilkinson, R.G. and Pickett, K. (2009), The Spirit Level: Why more equal societies almost always do better?, London, Allen Lane (Why Equality is Better for Everyone, Paperback $2^{\text {nd }}$ Edition, Penguin).

World Bank (2012), World Development Report 2012: Gender Equality and Development, WB Publications.

\section{Notes}

* Anis H. Bajrektarevic, $\mathrm{PhD}$, is the Chair of the International Law/Global Political Studies and the IMC Universitiy of Applied Sciences in Krems, Austria. President of the Young Lawyers Association of Bosnia-Herzegovina Bar in the 1980's, Dr. Bajrektarevic has worked in the diplomatic arena in numerous capacities since the early 1990's, and teaches courses in geo-political affairs, sustainable development, environmental ethics, international law and the European Union.

1. As Wilkinson and Pickett rightfully concluded, social ills like trust erosion, crimes, drugs abuse, political violence and the like are closely related to income inequality.

2. In other words; the selective R2P (Responsibility to Protect) without the Brazil-proposed and UNSCinstitutionalised RWP (Responsibility While Protecting) will remain too tempting for anyone wishing covert regime change. Therefore, the altruistically envisaged R2P doctrine increasingly loses its legitimacy.

3. Starting with the military deployments in Bosnia, Kosovo, Afghanistan, Iraq and Libya to the postconflict "resolution" momentum in these countries: it is always rather late in the process when most options are gone that we are asked to choose between what is left: bad and worse. Some would call it poor time-management: others would say it is a well-calibrated policy of timing.

4. As the concepts of an atheistic but of not decisively secularised and democratised state have historically failed, so the attempts of democracy without secularism are inevitably defeated. A secular state needn't necessarily be an atheistic one. It is simply an edifice that breeds a normative order of a rationalised administration, optimised economy and just society ready for true democratic contents.

5. Cybernetworks...cyberspace - an overstated buzzword whose importance people intuitively accept without really asking themselves what and why: Google is the most powerful database of information ever searched on internet, and Facebook is the most powerful database of persons ever on internet. From A. Bajrektarevic, Is There Life After Facebook, Addleton Academic Publishers RCP 11(2): 2012.

6. The expanded surveillance (disguised in freedoms promised) for many, the power and/or revenue for a few: the social media explosion of the last years finally enhanced the (self-) authentication of cyber residents. This, in return, has further assisted the monetisation of information on cyber lives and cyber data, as well as Minority Report movie-alike data fusion, including the pattern-based data mining and the so-called predictive network analysis. All that is for an unspecified number of state and non-state actors. According to a cyber-pioneer turned scholar, Eli Pariser, even "the private data broker Acxiom, for example, has an average of 1,500 items of data on $96 \%$ of Americans currently in its database." Cyber fascism? Well, not yet.

7. Former Italian State Secretary for Foreign Affairs, Ms. Marta Dassù makes a sharp and very accurate diagnosis: "A less pre-eminent U.S. therefore, opens up major questions for intra-European relations ... a vacuum filled first of all by France - rather than by Europe." (Europe's World, How Obama II is likely to see Europe, the EU Policy Journal Spring 2013/23, 96)

8. The post festum apology now comes from the newspapers that were trumpeting the early justifications for the US military involvement in Iraq (and elsewhere): “...And the war-having cost thousands of American lives and scores of thousands of Iraqi lives, having imposed financial costs vastly higher than the war's boosters predicted - left America weaker, not stronger, and ended up creating an Iraqi regime that is closer to Teheran than it is to Washington..." Then, the letter's author, Paul Krugman of the IHT, continues: “...if you hear that 'everyone' supports a policy, whether it's a war of choice or fiscal austerity, you should ask whether 'everyone' has been defined to exclude anyone expressing a different opinion. And policy arguments should be evaluated on the merits, not by who expresses them..." (IHT/New York Times, Marches of Folly, Paul Krugman, 19 March 2013, 7). Indeed, it is more than just these few nationalities of external authors ever admitted to the New York 
Times narrative. Despite this or similar periodic "regret letters", the phrase "international community position" will remain close to its original meaning; the jointly agreed Anglo-American policy action to which these two have coerced the rest of (Atlantic) Europe and the world, or the most of it.

9. The more Malaki's Bagdad-based government imposes its authoritarian rule on (Kurdish and Arab) Sunni areas and the oil-rich Basra region, the greater the chances for wider and deeper inter-ethnic unrest. The politico-military demands for larger territorial autonomies from Bagdad are on a steep rise. Practiced federalism surely optimises governability, but in the context of prevailing political cultures of the Middle East, it would inevitably lead to statehood disintegration. Simply, much of the seen limbo is an absence of war but also an absence of peace and progress. As we have witnessed in Bosnia, Libya, Afghanistan and Kosovo, federalism does not work without a domestication of authentic national reconciliation, at first. Turning Iraq (and adding Syria now) into a proxy battlefield between Iran and two confronted versions of Sunni Muslim world, that of Turkey and of Saudi Arabia, is a dangerous game without a beneficial epilogue for these on and those behind the scene.

10. There are two main reasons for Erdoğan's sudden deal with Ocalan/PKK. The domestic one is the expectation to win the votes of the pro-Kurdish BDP party that has 33 seats in Parliament. It is a support needed in the Prime Minister's quest for the constitutional change aimed to introduce the de Gaulle-like semi-presidential system in Turkey before expiration of his second term next year. The other reason is an attempt to equalise the increasing Iranian and Syrian influence over the Kurdish regions. Ankara lately improved relations with the Kurdish Regional Government of northern Iraq, but the influence of Turkish Kurds and its PKK is significantly counterbalanced by the Syrian PYD and Iranian PJAK Kurdish parties respectively. It is yet to be seen whether the Ocalan deal will remove the Kurdish threat from Turkish lands and break down the constraints Turkey suffers in northern portions of Iraq and Syria. 